\title{
A study of the selective catalytic hydroconversion of biomass-derived pyrolysis or fermentation liquids using propylamine and acetic acid as model reactants
}

\author{
A. C. Badari ${ }^{1}$, Sz. Harnos ${ }^{1}$, F. Lónyi ${ }^{1}$, Gy. Onyestyák ${ }^{1}$, M. Štolcováa ${ }^{2}$, A. Kaszonyi ${ }^{2}$, J. Valyon ${ }^{*}{ }^{* 1}$ \\ ${ }^{1}$ Institute of Materials and Environmental Chemistry, Research Centre for Natural Sciences, \\ Hungarian Academy of Sciences, Budapest, Pusztaszeri u. 59-67, 1025 Hungary \\ ${ }^{2}$ Department of Organic Technology, Slovak University of Technology, Radlinského 9, Bratislava, \\ SK-81237, Slovak Republic
}

(*) corresponding author: valyon.jozsef@ttk.mta.hu

\begin{abstract}
Silica-supported P or In modified Ni catalysts were active in the hydrodenitrogenation (HDN) and hydrodeoxygenation (HDO) of reactant propylamine (PA) and acetic acid (AA), respectively, which reactants were selected to model platform molecules of biomass origin. The undesired C-C hydrogenolysis activity of supported Ni catalyst, resulting in low value gaseous products, could be reined by the modification, generating silica-supported $\mathrm{Ni}_{2} \mathrm{P}$ and $\mathrm{Ni}_{2} \mathrm{In}$ active phases.
\end{abstract}

Keywords: bio-oil conversion, acetic acid HDO, propylamine $\mathrm{HDN}, \mathrm{Ni}_{2} \mathrm{In} / \mathrm{SiO}_{2}, \mathrm{Ni}_{2} \mathrm{P} / \mathrm{SiO}_{2}$

\section{Introduction}

The lignocellulosic materials, being mainly carbohydrate polymers, contain $\mathrm{O}$ as heteroatom [1], whereas the animal by-products, rich in proteins, which are polymers of amino acids, contain $\mathrm{N}$-heteroatoms [2]. The processing of these kinds of biomasses to higher value fuel or chemicals involves combinations of mechanical, thermal, chemical, and biological operations to destruct the polymeric chains. The conversion to organic liquid of higher energy density requires partial or full removal of heteroatoms from the biomaterial. The product obtained in the primary destructive treatment has a lower average molecular weight and it can have already reduced heteroatom content. For instance, the product derived from lignocellulosic materials by either pyrolytic or common hydrolysis and fermentation treatment contains lower carboxylic acids [3-5]. The pyrooil obtained from animal by-products contains only about $5 \mathrm{wt} \%$ organic oxygen and about $10 \mathrm{wt} \%$ organic nitrogen in $\mathrm{N}$-heterocycles, nitriles, amides or amines [2,6,7]. The average molecular weight of the components of latter bio-oil is near to $150[7,8]$.

The full $\mathrm{HDO}$ of lower $\mathrm{C}_{2}-\mathrm{C}_{4}$ carboxylic acids gives lower alkanes, which are relatively low value products compared to lower alcohols, which are products of partial HDO of the acids. A further advantage of the partial acid HDO is that it requires less costly hydrogen than the full HDO, moreover it gives lower amount of water, which is a worthless by-product of the HDO reaction. The selective heterogeneous catalytic HDO of lower carboxylic acids to alcohols needs 
catalyst that has high activity in the hydrogenolysis of the C-O bonds and in the further hydrogenation of the obtained aldehyde intermediate, but relatively low activity in the hydrogenolysis of C-C bonds and in the dehydration of monohydric alcohols. In the present study the AA that is common product of biological acidogenic and acetogenic carbohydrate degradation was selected as model compound to study the acid conversion to alcohol by selective partial catalytic HDO.

The pyrolysis of animal by-products provides a pyro-oil having a carbon to nitrogen atomic ratio of about 9 . The combustion of organic $\mathrm{N}$-compounds involves environmental hazard due to emission of flue gas, containing nitric oxides. The generation of fuel from such pyro-oil, therefore, requires full denitrogenation, preferably without significant cracking of the hydrocarbon moiety of the molecules. In principle, the selective total HDN of the oil provides hydrocarbons and ammonia that can be used to obtain fuel and $\mathrm{N}$-fertilizer, respectively. It is well known that the HDN of both nitriles and N-heterocycles proceeds through alkylamine intermediate [9]. Therefore, a simple amine, the PA was selected to study the processes of the catalytic HDN of nitrogen-rich pyro-oil.

For heteroatom removal from feedstock of fossil origin the petrochemical industry uses mostly sulfided $\mathrm{Co}, \mathrm{Mo} / \gamma$-alumina and $\mathrm{Ni}, \mathrm{Mo} / \gamma$-alumina catalysts $[10,11]$. However, bio-oils contain very different $\mathrm{O}$ - and $\mathrm{N}$-compounds than petrochemical feeds. Moreover, the $\mathrm{O}$ and $\mathrm{N}$ content of the oils are much higher than those of the petrochemical feeds. The sulfide catalysts are not favorable for processing bio-oils because these reactants, in contrast to those of fossil origin, are virtually free of sulfur [12]. Precious metal and Ni catalysts are known to have high hydrogenation activity also in absence of sulfur, however, this property is paralleled by hydrodecarbonylation and/or cracking activity that is not desired if we want to get liquid with high yield.

Recent studies showed that modification of supported Ni/silica catalysts by In or P generates surface $\mathrm{Ni}_{2} \mathrm{In}$ or $\mathrm{Ni}_{2} \mathrm{P}$ phases $[9,13]$. Present work shows that introduction of $\mathrm{In}$ or $\mathrm{P}$ suppresses the undesired side reactions proceeding over the $\mathrm{Ni} /$ silica catalyst. Both $\mathrm{Ni}_{2} \mathrm{P}$ and $\mathrm{Ni}_{2} \mathrm{In} / \mathrm{silica}$ catalysts are active and selective in the total HDN of amines to hydrocarbon and ammonia, whereas only the $\mathrm{Ni}_{2} \mathrm{In}$ catalyst has enhanced activity and selectivity in the hydrogenation of carboxylic acids to alcohols.

\section{Experimental}

A microporous silica gel (Sylobead B127, Grace Davison; diameter of the pores: smaller than about $2 \mathrm{~nm}$; specific surface area: $563 \mathrm{~m}^{2} / \mathrm{g}$ ) was applied as catalyst support. The silica-supported nickel phosphide catalyst, $\mathrm{Ni}_{2} \mathrm{P} /$ silica, was prepared by incipient wetness impregnation of the support by a solution of nickel phosphide precursor compounds, followed by drying, calcination 
and controlled reduction according to ref. [9]. First an aqueous impregnating solution was prepared by adding chemicals $\left(\mathrm{NH}_{4}\right)_{2} \mathrm{HPO}_{4}($ Fluka, $+99 \%)$ and $\mathrm{Ni}\left(\mathrm{NO}_{3}\right)_{2}(\mathrm{Merck},+99 \%)$ to water in an amount to set their concentrations to 4.6 and $2.3 \mathrm{~mol} / \mathrm{dm}^{3}$, respectively. Upon adding drops of concentrated nitric acid to the aqueous mixture a crystal clear green solution was obtained. Then, the dried silica was contacted with the impregnation solution by adding $0.5 \mathrm{~cm}^{3}$ of solution to each gram of the silica. The impregnated silica was dried at $120{ }^{\circ} \mathrm{C}$ for $6 \mathrm{~h}$ and calcined then at $400^{\circ} \mathrm{C}$ for $4 \mathrm{~h}$. The calcined sample was used as precursor of the $\mathrm{Ni}_{2} \mathrm{P} /$ silica catalyst. The supported $\mathrm{Ni}_{2} \mathrm{P}$ was obtained by heating the precursor up to $650{ }^{\circ} \mathrm{C}$ at a heating rate of $2{ }^{\circ} \mathrm{C} \min ^{-1}$ in flowing $\mathrm{H}_{2}\left(100 \mathrm{~cm}^{3} \mathrm{~min}^{-1}\right)$ and by continuing the $\mathrm{H}_{2}$ treatment at this temperature for $3 \mathrm{~h}$. Finally, the sample was cooled to room temperature in He flow $\left(20 \mathrm{~cm}^{3} \mathrm{~min}^{-1}\right)$ and contacted with a flow of $1.0 \% \mathrm{O}_{2} / \mathrm{He}\left(50 \mathrm{~cm}^{3} \mathrm{~min}^{-1}\right)$ at room temperature for $4 \mathrm{~h}$ to generate a phosphate-like surface layer over the pyrophoric $\mathrm{Ni}_{2} \mathrm{P}$ particles to prevent the bulk of the particles from becoming oxidized when exposed to air [14].

The silica supported $\mathrm{Ni}$ catalyst, $\mathrm{Ni} / \mathrm{SiO}_{2}$, was prepared similarly as the $\mathrm{Ni}_{2} \mathrm{P} /$ silica catalyst. The only difference was that the impregnating solution did not contain $\left(\mathrm{NH}_{4}\right)_{2} \mathrm{HPO}_{4}$. The impregnated silica was dried at $120^{\circ} \mathrm{C}$ for $6 \mathrm{~h}$, calcined at $450^{\circ} \mathrm{C}$ for $4 \mathrm{~h}$ to get the oxide precursor of the Ni-catalyst. The catalyst was obtained by treating the precursor in $\mathrm{H}_{2}$ flow at $500{ }^{\circ} \mathrm{C}$ for 3 h.

The $\mathrm{Ni}_{2} \mathrm{In} /$ silica catalyst was prepared from the $\mathrm{Ni}$ /silica catalyst precursor. The incipient wetness impregnation method was applied to introduce indium in the Ni-containing preparation. Each gram of the $\mathrm{Ni} /$ silica precursor was impregnated with $0.5 \mathrm{~cm}^{3} \operatorname{In}\left(\mathrm{NO}_{3}\right)_{3}$ solution, having In concentration of $2.3 \mathrm{~mol} / \mathrm{dm}^{3}$, i. e., the Ni to In atomic ratio of the preparation corresponded to 2 to 1 . The sample was dried, calcined to get the oxide precursor of the $\mathrm{Ni}_{2} \mathrm{In} /$ silica catalyst. The catalyst was obtained by reduction of the precursor in $\mathrm{H}_{2}$ flow at $450{ }^{\circ} \mathrm{C}$ for $1 \mathrm{~h}$. The chemical composition and the specific surface area of the catalyst samples are summarized in Table 1.

X-ray powder diffraction (XRD) examinations were carried out using a Philips PW 1810/3710 diffractometer equipped with an XRD cell that allowed in situ reduction of the catalyst precursors with hydrogen at selected temperatures. After $\mathrm{H}_{2}$ treatments the XRD patterns were recorded at room temperature applying monochromatized $\mathrm{CuK \alpha}(\lambda=0.15418 \mathrm{~nm})$ radiation $(40 \mathrm{kV}, 35 \mathrm{~mA})$ and a proportional counter.

The morphology of the samples was characterized by electron micrograph (TEM micrograph), moreover, by SSA and pore size distribution (PSD). The SSA and PSD were derived from the low-temperature $\left(-196{ }^{\circ} \mathrm{C}\right) \mathrm{N}_{2}$ adsorption isotherms of the samples. The TEM pictures were obtained by a FEI Morgagni 268D type microscope, whereas the adsorption isotherms were 
determined by Quantachrome NOVA Automated Gas Sorption Instrument. Before adsorption measurements the samples were evacuated at $350^{\circ} \mathrm{C}$ for $1 \mathrm{~h}$.

The HDO and HDN reactions of acetic acid (AA) and propylamine (PA) model compounds, respectively, were studied over silica-supported catalysts using high-pressure flow-through microreactor. The HDO of AA was carried out at $1.0 \mathrm{~h}^{-1} \mathrm{WHSV}$ and 21 bar pressure, whereas the HDN of PA was carried out at $1.0 \mathrm{~h}^{-1} \mathrm{WHSV}$ and 30 bar pressure. The partial pressures of PA and AA were 2.7 and 2.1 bar, respectively. Each catalyst samples were tested for about two weeks in order to measure the temperature $\left(200-400{ }^{\circ} \mathrm{C}\right)$ and space time $\left(0.25-2.0 \mathrm{~h} \times \mathrm{g}_{\text {catalyst }} / \mathrm{g}_{\text {reactant }}\right)$ dependence of the reactions, while several measurements at a given set of parameters were repeated in order to check the stability of the catalysts. All the catalysts showed stable activity during this time period. No coke deposition was perceptible to the eye on the catalysts removed from the reactor. The carbon content of the feed and the products was virtually equal.

The composition of the reactor effluent was analyzed by on-line gas chromatograph (Shimadzu GC-2010 Plus) equipped with an Equity-1 fused silica capillary column (Supelco) and a flame ionization detector.

\section{Results and Discussion}

The XRD patterns of the catalysts, obtained by in situ reduction of the catalyst precursors are shown in Fig. 1. The $\mathrm{Ni} / \mathrm{SiO}_{2}$ catalyst presents weak reflection lines at $44.5^{\circ}$ and $52.0^{\circ}$ characteristic of $\mathrm{Ni}$ metal particles. The reflections at $2 \Theta$ degrees of 28.9 and $43.2^{\circ}$ prove the presence of the $\mathrm{Ni}_{2} \mathrm{In}$ phase in the $\mathrm{Ni}_{2} \mathrm{In} / \mathrm{SiO}_{2}$ catalyst [13]. Note that neither In nor Ni phase was detectable. The 40.6, 44.6, 47.3, 54.2, and $54.9^{\circ}$ XRD reflections stem from the crystalline $\mathrm{Ni}_{2} \mathrm{P}$ phase of the $\mathrm{Ni}_{2} \mathrm{P} / \mathrm{SiO}_{2}$ catalyst [9].

The average particle size of the active $\mathrm{Ni}, \mathrm{Ni}_{2} \mathrm{In}$, and $\mathrm{Ni}_{2} \mathrm{P}$ phases on the silica support was determined from the XRD data by the Scherrer equation (Table 1). The TEM pictures of Fig. 2 allowed us to draw conclusions also about the size distribution of the active particles (Table 1). The SSA of the silica support and that of the $\mathrm{Ni} / \mathrm{SiO}_{2}$ catalyst was nearly the same. In contrast, the $\mathrm{Ni}_{2} \mathrm{P} / \mathrm{SiO}_{2}$ and $\mathrm{Ni}_{2} \mathrm{In} / \mathrm{SiO}_{2}$ catalysts were of significantly lower SSA than the support (Table 1). The $\mathrm{N}_{2}$ adsorption isotherm of the samples is of type I (Fig. 2D). Adsorption hysteresis is essentially absent, suggesting that the materials are purely microporous. The micropore structure was characterized by PSD curves, determined from the isotherms using the MP method (Fig. 2). The pores of about $1 \mathrm{~nm}$ diameter represent the highest pore volume in the support as well as in the catalysts. Therefore, the crystallites of active phase, having critical dimension commensurable with the pore sizes or much larger than those are. The smaller particles can block some of the micropores of the $\mathrm{Ni}_{2} \mathrm{In} / \mathrm{SiO}_{2}$ catalyst from $\mathrm{N}_{2}$ adsorption and might be responsible for the lower 
surface area of the catalyst than that of the support (Table 1). The particles of the $\mathrm{Ni}_{2} \mathrm{P} / \mathrm{SiO}_{2}$ are 20-60 nm size, i. e., they are much larger than the pore sizes. The TEM picture of the $\mathrm{Ni}_{2} \mathrm{P} / \mathrm{SiO}_{2}$ catalyst (Fig. 2A) does not substantiate small particles that could block the micropores of the support. Nevertheless, the surface area of latter catalyst is much smaller than that of the support. Notice that the sample contains about three times as much phosphorus, than that, corresponding to the $\mathrm{Ni}_{2} \mathrm{P}$ stoichiometry. Some pores of the silica must be blocked by surface bound $\mathrm{PO}_{\mathrm{x}}$ species.

The Ni/silica catalyst shows both HDO and HDN activities (Figs. 3A,B). The AA conversion increased with the increasing reaction temperature (Fig. 3A). A fraction of the ethanol, formed as hydrogenation product, gave ester by reacting with the non-converted acid. The yield of ethanol paralleled the increase of the conversion, whereas the ethyl acetate yield changed in opposite direction suggesting that ester is a secondary source of ethanol. The formation of methane in significant amount indicates that the Ni-catalyst has high hydrogenolysis/hydrogenation activity. A possible route of methane formation is the decarboxylation of the AA reactant or hydrodecarbonylation the acetaldehyde intermediate of the reaction [15]. If $\mathrm{CO}_{2}$ and $\mathrm{CO}$ was formed at all they must have been readily converted to methane over the active $\mathrm{Ni} / \mathrm{silica}$ hydrogenation catalyst.

Below about $300{ }^{\circ} \mathrm{C}$ the main products of PA hydroconversion over the $\mathrm{Ni} /$ silica catalyst were dipropylamine (DPA) and ammonia (Fig. 3B). These are products of PA disproportionation generally observed on supported Ni catalysts [16]. Minor amounts of tripropylamine (TPA) and propane were also obtained. Full hydrodenitrogenation was achieved above $350{ }^{\circ} \mathrm{C}$ only. However, besides the desired products of propane and ammonia, methane and ethane was also formed in significant amount. The appearance of latter products shows that the Ni/silica catalyst is active in the $\mathrm{C}-\mathrm{C}$ bond hydrogenolysis.

In the $\mathrm{HDO}$ reaction of $\mathrm{AA}$ the $\mathrm{Ni}_{2} \mathrm{P} /$ silica catalyst showed similar catalytic properties than the $\mathrm{Ni} /$ silica catalyst, except that not only methane but methane and $\mathrm{CO}$ in equal amounts were formed (cf. Figs. 3A and 3C). These results indicate that phosphorus modification did not decrease the hydrogenation activity of $\mathrm{Ni}$ to an extent to prevent the attack of the $\mathrm{C}$ - $\mathrm{C}$ bond between the methyl and carbonyl group in the AA or the acetaldehyde molecules. The HCOOH or $\mathrm{HCOH}$ primary products of the $\mathrm{C}-\mathrm{C}$ bond hydrogenolysis must have been rapidly decomposed to give $\mathrm{CO}_{2}$ and $\mathrm{CO}$. Methanization of latter products did not proceed, explaining the equivalency of methane to carbon monoxide in the product mixture.

In the $\mathrm{HDN}$ of $\mathrm{PA}$ the $\mathrm{Ni}_{2} \mathrm{P} /$ silica catalyst was less active than the $\mathrm{Ni} /$ silica below about $300{ }^{\circ} \mathrm{C}$ (cf. Figs. 3B and 3D). The main reaction was PA disproportionation to DPA and ammonia. The propane yield was minor. At temperatures above about $300{ }^{\circ} \mathrm{C}$ the hydrodenitrogenation of the 
DPA intermediate speeded up and lower steady-state DPA intermediate concentrations were established (Eq.1).

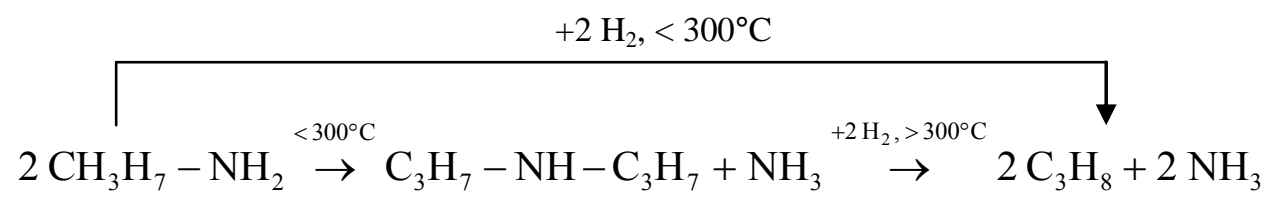

At a reaction temperature of about $400{ }^{\circ} \mathrm{C}$ the PA conversion was near to $90 \%$, mainly ammonia and propane was formed in about equal molar amounts. It is to be noted that methane and ethane could not be detected in the reactor effluent. The $\mathrm{Ni}_{2} \mathrm{In} /$ silica catalyst showed nearly the same catalytic properties in the $\mathrm{HDN}$ of PA as the $\mathrm{Ni}_{2} \mathrm{P} /$ silica catalyst (cf. Figs. 3D and $3 \mathrm{~F}$ ), except that it showed higher activity below about $300{ }^{\circ} \mathrm{C}$. Unlike to the Ni/silica catalyst neither $\mathrm{Ni}_{2} \mathrm{P} /$ silica, nor $\mathrm{Ni}_{2} \mathrm{In} /$ silica shows activity in the hydrogenolysis of aliphatic C-C bonds.

The AA hydroconversion, parallel with the ethanol yield, increases more rapidly with the temperature over the $\mathrm{Ni}_{2} \mathrm{In} /$ silica than over the $\mathrm{Ni} /$ silica catalyst (cf. Figs. 3A and 3E). This infers that the In modification increased the activation energy of the AA conversion. Already at about $350{ }^{\circ} \mathrm{C}$ near to full conversion was obtained. The only products were practically ethanol and water. Minor amounts of acetaldehyde and ethyl acetate were also formed. In contrast, acetaldehyde and ethyl acetate were the main products at low conversions below about $330{ }^{\circ} \mathrm{C}$. Former is the intermediate of alcohol formation whereas latter is a side product coming from the reaction of the product alcohol and the non-reacted acid [15]. At higher temperatures both were hydrogenated to alcohol. It is to be noticed that no methane, $\mathrm{CO}$ or $\mathrm{CO}_{2}$ were formed. The main reaction proceeds through acetaldehyde/vinyl alcohol tautomers (Eq.2).

$$
\mathrm{CH}_{3}-\mathrm{COOH} \underset{-\mathrm{H}_{2} \mathrm{O}}{\stackrel{+\mathrm{H}_{2}}{\longrightarrow}}\left[\mathrm{CH}_{3}-\mathrm{CHO} \leftrightarrow \mathrm{CH}_{2}=\mathrm{CH}-\mathrm{OH}\right] \stackrel{+\mathrm{H}_{2}}{\rightarrow} \mathrm{CH}_{3}-\mathrm{CH}_{2}-\mathrm{OH}
$$

Curves of $\mathrm{AA}$ and PA hydroconversion over $\mathrm{Ni}_{2} \mathrm{In} /$ silica and $\mathrm{Ni}_{2} \mathrm{P} /$ silica catalysts were compared as a function of space time (Fig. 4). The yields of acetaldehyde, ethyl acetate (Fig. 4A), and DPA (Fig. 4B) passed through maximum indicating that these products were intermediates of a consecutive hydroconversion process.

The $\mathrm{Ni}_{2} \mathrm{In} /$ silica catalyst exhibited high selectivity in the HDO of AA to ethanol and nearly the same high selectivity in the HDN of PA to propane and ammonia. In contrast, the $\mathrm{Ni} 2 \mathrm{P} /$ silica catalyst was very selective in the PA HDN reaction but had undesired hydrodecarbonylation activity in the HDO of AA. The suppressed C-C hydrogenolysis and CO hydrogenation of the modified catalysts could be due to the insertion of $\mathrm{P}$ or In atoms between the surface Ni atoms decreasing the electron density of the surface and, thereby rendering reactant and $\mathrm{C}-\mathrm{C}, \mathrm{C}-\mathrm{O}$, and 
$\mathrm{H}-\mathrm{H}$ bond activation more difficult than over pure Ni surfaces. The In modifier does not only rein the hydrogenation activity of $\mathrm{Ni}$, but direct the $\mathrm{HDO}$ reaction from the hydrogenolysis/hydrogenation to the hydrogenation/dehydration pathway.

\section{Conclusions}

The present paper shows that a highly active $\mathrm{Ni} /$ silica hydrogenation catalyst is not favored for HDO and HDN reactions because they initiate undesired hydrogenolysis/hydrogenation side reactions giving alkanes, having lower carbon number than the reactant aliphatic carboxylic acid or amine. However, the $\mathrm{Ni}$ alloying with $\mathrm{In}$ or $\mathrm{P}$ gives $\mathrm{Ni}_{2} \mathrm{In}$ and $\mathrm{Ni}_{2} \mathrm{P}$ phases on the silica support that are active and selective in the partial or full removal of heteroatoms in a hydroconversion process without breaking $\mathrm{C}-\mathrm{C}$ bonds.

The results obtained for the catalytic hydroconversion of AA suggest that it is possible to obtain high yields of lower alcohols from biocarboxylic acids by selective catalytic partial hydrodeoxygenation under relatively mild reaction conditions using $\mathrm{Ni}_{2} \mathrm{In} / \mathrm{silica}$ catalysts. It was also shown that PA can be selectively hydroconverted to propane and ammonia over both $\mathrm{Ni}_{2} \mathrm{P} /$ silica and $\mathrm{Ni}_{2} \mathrm{In} /$ silica catalysts under relatively mild reaction conditions. The presented results suggest that $\mathrm{N}$-containing organic compounds, such as pyro-oil from animal by-products, can be hydroconverted to valuable hydrocarbon mixture and ammonia.

\section{Acknowledgement}

Thanks is due to the Hungary-Slovakia Cross-border Co-operation Program (Project registration number: HUSK/1101/1.2.1/0318) for supporting this research.

\section{References}

[1] D.A. Bulushev, J.R.H. Ross, Catal. Today 171 (2011) 1-13.

[2] E. Cascarosa, G. Gea, J. Arauzo, Renew. Sust. Energ. Rev. 16 (2012) 942-957.

[3] G.W. Huber, S. Iborra, A. Corma, Chem. Rev. 106 (2006) 4044-4098.

[4] S.N. Naik, V.V. Goud, P.K. Rout, A.K. Dalai, Renew. Sust. Energ. Rev. 14 (2010) 578-597.

[5] H.N. Chang, N.-J. Kim, J. Kang, C.M. Jeong, Biotechnol. Bioprocess Eng. 15 (2010) 1-10.

[6] M. Ayllón, M. Aznar, J.L. Sánchez, G. Gea, J. Arauzo, Chem. Eng. J. 121 (2006) 85-96.

[7] E. Cascarosa, I. Fonts, J.M. Mesa, J.L. Sánchez, J. Arauzo, Fuel Process. Technol. 92 (2011) 1954-1962.

[8] F. Lónyi, J. Valyon, E. Someus, and J. Hancsók, Fuel 112 (2013) 23-30.

[9]S.T. Oyama, Y.-K. Lee, J. Phys. Chem. B 109 (2005) 2109-2119.

[10] E. Furimsky, Appl. Catal. A 199 (2000) 147-190.

[11] E. Furimsky, F.E. Massoth, Catal. Rev. - Sci. Eng. 47 (2005) 297-489.

[12] P.M. Mortensen, J.-D. Grunwaldt, P.A. Jensen, K.G. Knudsen, A.D. Jensen, Appl. Catal. A 407 (2011) $1-19$.

[13] Gy. Onyestyák, Sz. Harnos, D. Kalló, in: Indium: Technological Applications and Health Issues. Nova Publishers, New York, 2013. Chapter 2, pp. 53-79.

[14] S. J. Sawhill,D. C. Phillips, M. E. Bussell, J. Catal. 215 (2003) 208-219.

[15] E. Furimsky, Catal. Today 217 (2013) 13-56.

[16] M.J.F.M. Verhaak, A.J. van Dillen, J.W. Geus, Appl. Catal. A 109 (1994) 263-275. 


\section{Figure captions}

Fig. 1. X-ray diffractograms of catalyst (a) $\mathrm{Ni}_{2} \mathrm{P} / \mathrm{SiO}_{2}$, (b) $\mathrm{Ni} / \mathrm{SiO}_{2}$, and (c) $\mathrm{Ni} 2 \mathrm{In} / \mathrm{SiO}_{2}$. $\mathrm{The}$ samples were pretreated in situ in $\mathrm{H}_{2}$ flow using a high-temperature XRD cell at the indicated temperature prior recording the XRD patterns at room temperature.

Fig. 2. TEM micrographs of (A) $\mathrm{Ni}_{2} \mathrm{P} / \mathrm{SiO}_{2}$, (B) Ni/SiO${ }_{2}$, and (C) $\mathrm{Ni}_{2} \mathrm{In} / \mathrm{SiO}_{2}$ catalysts. Segment $\mathrm{D}$ shows the $\mathrm{N}_{2}$ adsorption isotherms of the support and the In and P-modified supported $\mathrm{Ni}$ catalysts at $-196{ }^{\circ} \mathrm{C}$, whereas segment $\mathrm{E}$ shows the PSD of micropores determined from the isotherms using the MP method.

Fig. 3. The hydroconversion of $(A, C, E)$ AA and (B,D,F) PA over (A, B) Ni/silica, (C, D) $\mathrm{Ni}_{2} \mathrm{P} /$ silica, and $(\mathrm{E}, \mathrm{F}) \mathrm{Ni}_{2} \mathrm{In} /$ silica catalysts as function of temperature. The HDO of AA was carried out at $1.0 \mathrm{~h}^{-1}$ WHSV and 21 bar pressure, whereas the HDN of PA was carried out at $1.0 \mathrm{~h}^{-1} \mathrm{WHSV}$ and 30 bar pressure. The partial pressures of PA and AA were 2.7 and 2.1 bar, respectively.

Fig. 4. The hydroconversion of (A) AA over $\mathrm{Ni}_{2} \mathrm{In} /$ silica and (B) PA over $\mathrm{Ni}_{2} \mathrm{P} /$ silica catalyst as a function of space time. The HDO of AA was carried out at 21 bar pressure and $350{ }^{\circ} \mathrm{C}$. The HDN of PA was studied at $375^{\circ} \mathrm{C}$ at a total pressure of 30 bar. The partial pressures of PA and AA were 2.7 and 2.1 bar, respectively. 
Table 1. Characterization of the catalysts

\begin{tabular}{lcccccc}
\hline Sample & $\mathrm{SSA}^{\mathrm{a}}{ }^{\mathrm{a}} \mathrm{m}^{2} \mathrm{~g}^{-1} \sum \mathrm{V}_{\mathrm{p}}{ }^{\mathrm{b}} \mathrm{cm}^{3} \mathrm{~g}^{-1}$ & $\mathrm{Ni}, \mathrm{wt} \%$ & $\mathrm{P}, \mathrm{wt} \%$ & $\mathrm{In}, \mathrm{wt} \%$ & $\mathrm{D},{ }^{\mathrm{c}} \mathrm{nm}$ \\
\hline $\mathrm{SiO}_{2}$ & 563 & 0.41 & & & & \\
$\mathrm{Ni} / \mathrm{SiO}_{2}$ & 558 & - & 6.76 & - & - & $2-10(11)$ \\
$\mathrm{Ni}_{2} \mathrm{P} / \mathrm{SiO}_{2}$ & 268 & 0.15 & 5.04 & 4.11 & - & $20-60(49)$ \\
$\mathrm{Ni}_{2} \mathrm{In} / \mathrm{SiO}_{2}$ & 299 & 0.19 & 6.76 & - & 8.3 & $2-10(10)$ \\
\hline
\end{tabular}

${ }^{\mathrm{a}} \mathrm{SSA}=$ specific surface area, determined by the Brunauer-Emmett-Teller (BET) method.

${ }^{\mathrm{b}} \Sigma \mathrm{V}_{\mathrm{p}}$, = total pore volume. The volume of liquid $\mathrm{N}_{2}$, equivalent with the saturation $\mathrm{N}_{2}$ adsorption capacity, was assumed to be equal with $\Sigma \mathrm{V}_{\mathrm{p}}$.

${ }^{c}$ Diameter of particles of the active phase observed in the TEM micrograph (particle size determined from XRD by Scherrer equation is given in parentheses). 
Fig. 1.

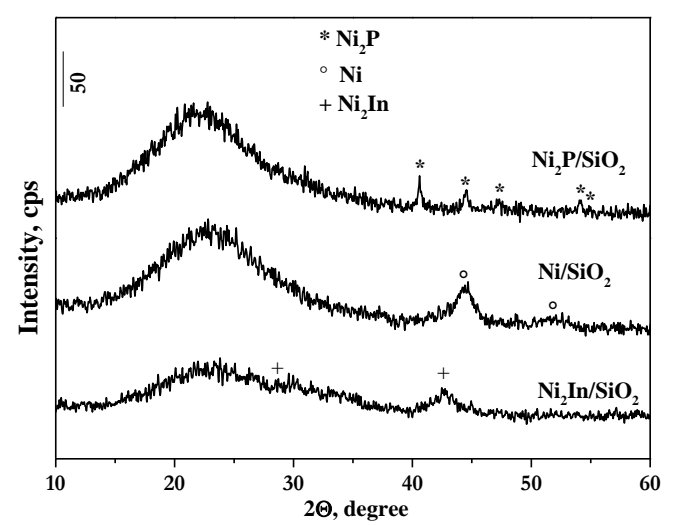


Fig. 2.

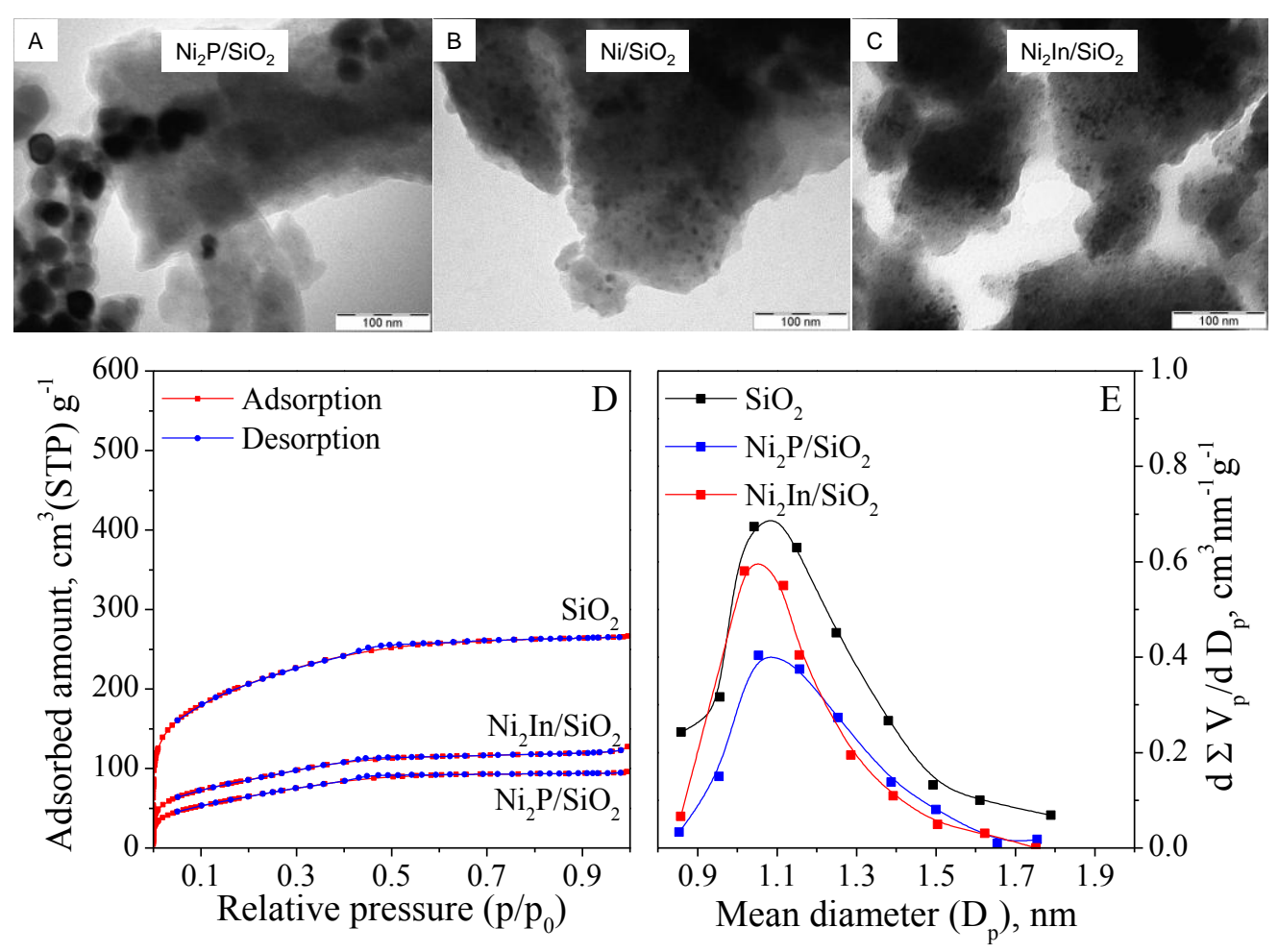


Fig. 3.

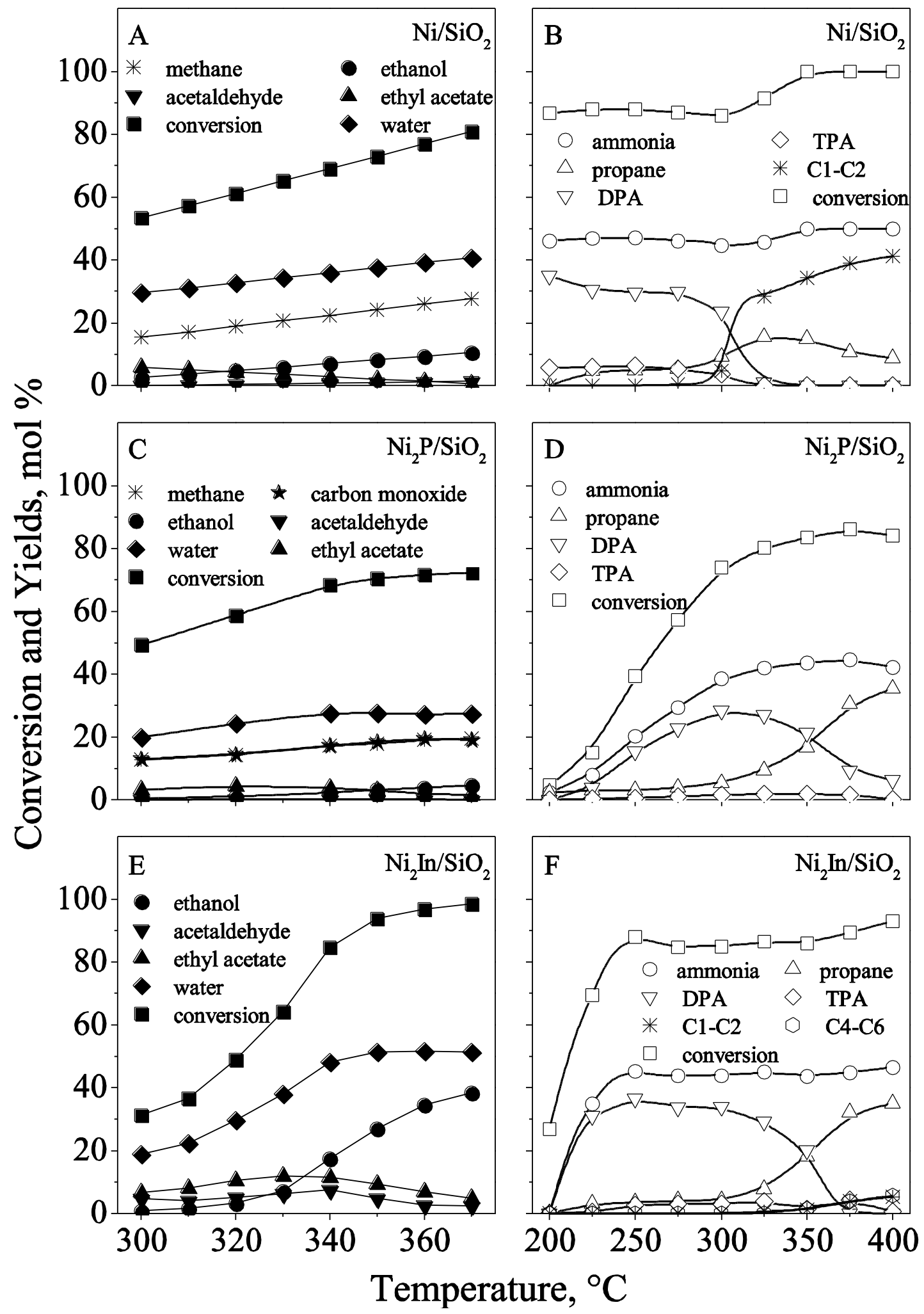


Fig. 4.
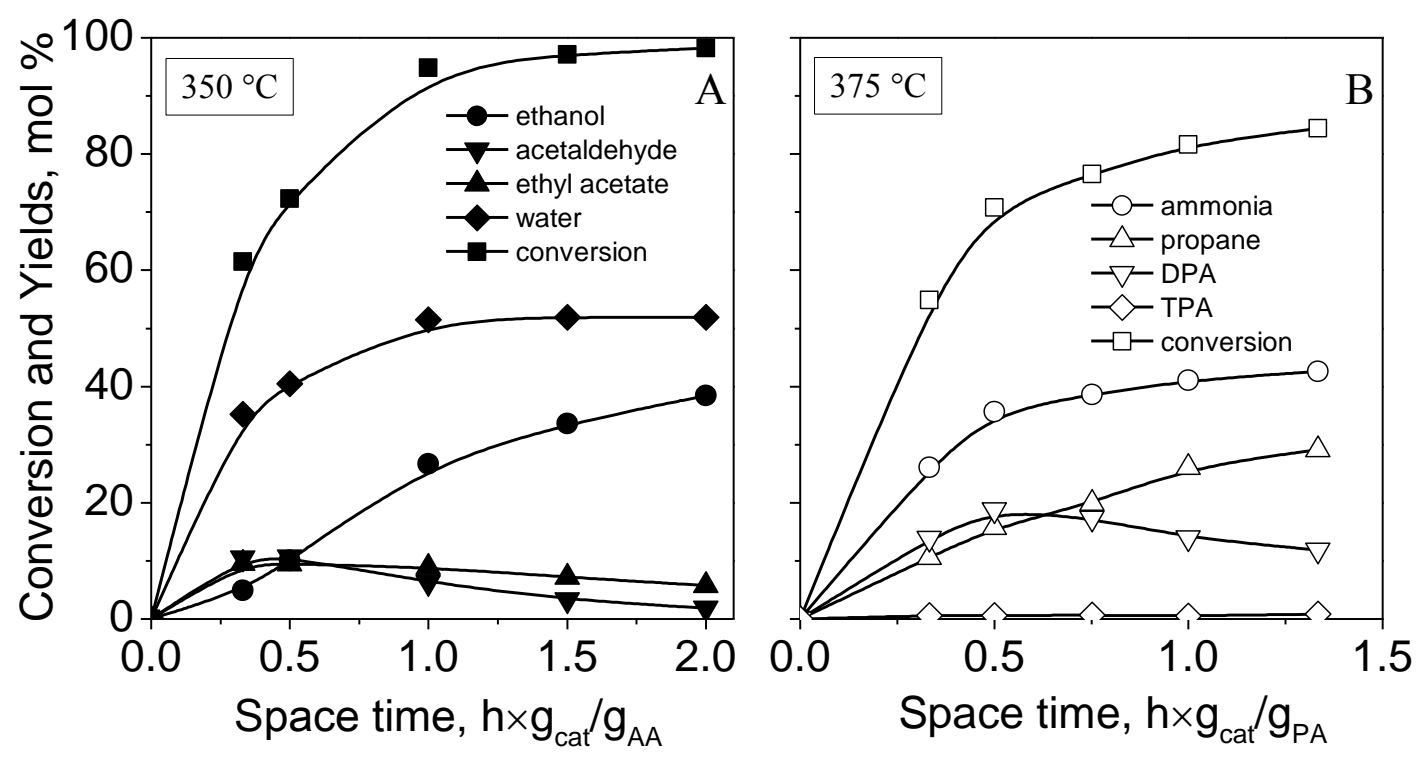